19 ZwarardemakerH. Der Verlaustau hohen Tonen mit zunehmendem Alter. Ein neves Gesetz. Arch Ohr Nas und Kehlkoptheilkunde 1874;32:53-6.

20 Kiessling L, Pichora-Fuller MK, Gatehouse S, et al. Candidature for and delivery of audiological services: special needs of older people. Int J Audiol 2003:42:2S92-101.

21 Arnesen AR. Presbyacusis - loss of neurons in the human cochlear nuclei. $J$ Laryngol Otol 1982;96:503-11.

22 Pichora-Fuller MK, Souza PE. Effects of aging on auditory processing of speech. Int J Audiol 2003;42:2S1 1-16.

23 Luxon LM. The anatomy and pathology of the central auditory pathways. Br J Audiol 1981;15:31-40.

24 Jennings CR, Jones NS. Presbyacusis. J Laryngol Otol 2001;115:171-8.

25 Gates GA, Myers RH. Genetic associations in age-related hearing thresholds. Arch Otolaryngol Head Neck Surg 1999;125:654-9.

26 Ensink RJ, Camp GV, Cremers CW. Mitochondrial inherited hearing loss. Clin Otolaryngol 1998;23:3-8.

27 Wright A, Forge A, Kotecha B. Ototoxicity. In: Booth JB, eds. Scott Browns otolaryngology. Vol 3. Otology. Oxford: Butterworth Heinemann, 1997:3/ 20/1-2/20/31.

28 Lim DP, Stephens SDG. Clinical investigation of hearing loss in the elderly. Clin Otolaryngol 1991;16:288-93.

29 Schacht J. Aminoglycoside ototoxicity: prevention in sight? Otolaryngol Head Neck Surg 1998;118:674-7.

30 British Medical Association and Royal Pharmaceutical Society of Great Britain. British National Formulary 50, Sep 2005. London: British Medical Association and Royal Pharmaceutical Society of Great Britain, 2005.

31 Brors D, Bodmer D. New aspects of inner ear research. BrJ Hosp Med 2004;65:392-5.

32 Gates GA, Cobb JL, D'Agostino RB, et al. The relation of hearing in the elderly to the presence of cardiovascular risk factors. Arch Otolaryngol Head Neck Surg 1993;119:156-61.

33 Brown CG, Gatehouse S, Lowe GD. Blood viscosity as a factor in sensorineural hearing impairment. Lancet 1986;i:121-3.

34 Rosen S, Olin P. Hearing loss and coronary heart disease. Arch Otolaryngol Head Neck Surg 1965;82:236-43.

35 Rosen S, Olin P, Rosen HV. Dietary prevention of hearing loss. Acta Otolaryngol 1970;70:242-7.
36 Yamazaki T, Ogwa K, Imoto T, et al. Senile deafness and metabolic bone disease. Am J Otol 1988;9:376-82.

37 Tay HL, Ray N, Ohri R, et al. Diabetes mellitus and hearing loss. Clin Otolaryngol 1995;20:130-4.

38 Hall SJ, Kerr AG, Varghese M, et al. Deafness in hypothyroidism. (Abstract). Clin Otolatyngol 1985;10:292.

39 Gates GA, Karzon RK, Garcia P, et al. Auditory dysfunction in aging and senile dementia of the Alzheimer's type. Arch Neurol 1995;52:626-34.

40 Anonymous. Hearing problems in elderly people: implications for services. Lancet 1987;i:1181-2.

41 W einstein BE. Geriatric hearing loss: myths, realities, resources for physicians. Geriatrics 1989;44:42-60.

42 Pichora-Fuller MK. Cognitive aging and auditory information processing Int J Audiol 2003;42:2S26-32.

43 Mulrow CD, Aguilar C, Endicot JE, et al. Quality of life changes and hearing impairment: a randomised trial. Ann Intern Med 1990;113:118-94.

44 Keller BK, Morton JL, Thomas VS, et al. The effect of visual and hearing impairments on functional status. J Am Geriatr Soc 1999;47:1319-25.

45 A rlinger S. Negative consequences of uncorrected hearing loss - a review. Int J Audiol 2003;422S17-20..

46 Sekuler R, Blake R. Sensory underload. Psychology Today 1987;21:48-53.

47 Gennis V, Garry PJ, Haaland KY, et al. Hearing and cognition in the elderly. Arch Intern Med 1991;151:2259-64.

48 Fisch U. Management of sudden deafness. Otolaryngol Head Neck Surg 1983;91:3-8.

49 Kveton JF. Evaluation and management of acoustic neuroma. Current Opinion in Otolaryngology and Head and Neck Surgery 1993;1:53-63.

50 Snik AFM, Mylanus EAM, Cremers CWRG. Implantable hearing devices for sensorineural hearing loss: a review of the audiometric data. Clin Otolaryngol 1998;23:414-19.

51 Izumikawa M, Minoda R, Kawamoto K, et al. Auditory hair cell replacement and hearing improvement by Atohl gene therapy in deaf mammals. Nature Medicine. 2005; 11: 3, 271-6.

52 Ito J, Kojima K, Kawaguchi S. Survival of neural stem cells in the cochlea. Acta Otolaryngol 2001;121:140-2

\title{
CORRECTIO N
}

doi: 10.1136/pgmj.2003.006577corr1

Following the decision of the General Medical Council's Fitness to Practise Panel, ${ }^{1}$ the publisher is issuing a correction that affects the authorship of a letter published in the Postgraduate Medical Journal. ${ }^{2}$ Following the panel's decision, this paper should now always be cited as: Bird AD. Cost effective strategy for a safe diagnosis of deep vein thrombosis at a district general hospital. Postgrad Med J 2003;79:363.

M s Bird acknowledges the help of Dr J I G Strang, Dr R Winter, and Mr R Hibberd.

$1 \mathrm{http}: / /$ www.gmc-uk.org/concerns/decisions/search_database/ftp_panel_ sinharay_20051122.asp

2 Sinharay R, Strang G, Bird D. Cost effective strategy for a safe diagnosis of DVT at a district general hospital. Postgrad Med J 2003;79:363. 